\title{
ПРОБЛЕМНЫЕ ВОПРОСЫ ПРАВОВОГО РЕГУЛИРОВАНИЯ БЛАГОТВОРИТЕЛЬНЫХ СБОРОВ, ПРОВОДИМЫХ ФИЗИЧЕСКИМИ ЛИЦАМИ В РЕСПУБЛИКЕ КАЗАХСТАН
}

\section{PROBLEMATIC ISSUES OF LEGAL REGULATION OF CHARITABLE COLLECTIONS HELD BY INDIVIDUALS IN THE REPUBLIC OF KAZAKHSTAN}

D. Martsinechko

Summary. This article discusses the issue of imperfection of the legislation of the Republic of Kazakhstan in the field of charity. As practice shows, today a large number of fees opened by individuals are fraudulent, in this regard, there is a need to eliminate the imperfections of legislation that allow the organization of such fees by individuals. In the course of writing the article, the author analyzed the current legislation of the Republic of Kazakhstan with regard to charity, identified its weaknesses and proposed measures to eliminate them.

Keywords: charity; charity fee; charity regulation; legal regulation of fees; fraud.

\author{
Марцинечко Дарья Вадимовна \\ Казахский университет международных отношений \\ и мировых языков им. Абылай хана, г. Алматы, \\ Казахстан \\ daria.martsinechko@yandex.ru
}

Аннотация. В данной статье рассматривается вопрос несовершенства законодательства Республики Казахстан в сфере благотворительности. Как показывает практика, на сегодняшний день большое количество сборов, открываемых физическими лицами, является мошенническими, в связи с этим, видится необходимость в устранении несовершенств законодательства, позволяющих организацию таких сборов физическими лицами. В ходе написания статьи автором был проведен анализ текущего законодательства Республики Казахстан, касаемо благотворительности, выявлены его слабые стороны и предложены меры по их устранению.

Ключевые слова: благотворительность; благотворительный сбор; регулирование благотворительности; правовое регулирование сборов; мошенничество.

следствии не предоставляют никакой отчетности благотворителям, оставляя их в неведении, о направленности собранной материальной помощи.

Вместе с тем, в настоящее время становится актуальным вопрос о правовом обеспечении безопасности благотворителей, под которой понимается защита интересов благотворителей от неправомерных действий физических и юридических лиц (фондов) в сфере благотворительности.

Республике Казахстан, как современному правовому государству, необходимо усовершенствовать законодательство в сфере благотворительности, поскольку на данный момент, оно имеет достаточное количество недочетов, позволяющих организовывать «токсичные» сборы. На сегодняшний день благотворительная деятельность в Республике Казахстан регулируется Законом «О благотворительности». 
В Законе благотворительность определяется как социально-полезная деятельность, направленная на удовлетворение гуманных потребностей, осуществляемая добровольно.

Так, Закон предусматривает правовое регулирование только тех благотворительных сборов, которые проводятся благотворительными организациями. Закон вводит понятие благотворительной организации «Некоммерческая организачия, созданная физическими либо юридическими лицами для выполнения задач благотворительности» [1].

Правомерность проведения благотворительных сборов физическими лицами Законом не определена. Из этого следует, что сборы на территории Республики Казахстан физическими лицами либо не могут проводиться, либо их проведение не регулируется нормами настоящего Закона.

Организация «непрозрачного» сбора является достаточно распространенной на данный момент схемой мошенничества. В связи с этим количество пострадавших от такого вида злоупотребления доверием постоянно растет.

Открытым остается вопрос о том, как открывать и проводить благотворительные сборы физическим лицам в Республике Казахстан. Здесь видится несколько решений:

\section{1. Полный запрет на проведение благотворительных сборов физическими лицами}

Запрет на проведение благотворительных сборов физическими лицами обусловлен тем, что большое количество таких сборов является «непрозрачным», а это значит, что отчета по полученным средствам и их целевому использованию нет. Cm. 516 ГК РК устанавливает, что пожертвование делается с определенным назначением. В случае, если пожертвование использовано не по назначению, жертвователь имеет право отменить свое пожертвование. Как показывает практика, организаторы таких сборов не возвращают внесенное пожертвование.

Полный запрет на проведение сборов физическими лицами подразумевает, что в случае возникшей необходимости, физическое лицо обращается напрямую в благотворительный фонд с целью содействия в получении необходимой материальной помощи. Благотворительный фонд, в свою очередь, начинает процесс организации благотворительного сбора в соответствии с законодательством Республики Казахстан. Так же, за- прет на проведение сборов физическими лицами влечет за собой и изменения в виде внесения соответствующих статей в КоАП РК либо УК РК. Такая мера является радикальной, поскольку полный запрет на проведение сборов физическими лицами увеличит нагрузку на фонды.

На данный момент, в случае обнаружения нечестного и непрозрачного ведения благотворительного сбора и последующего обращения жертвователей в правоохранительные органы Республики Казахстан, в отношении организаторов такого сбора возбуждается уголовное дело по ст. 190 УК РК «Мошенничество» [3]. Как известно, мошенничество является преступлением на доверии, именно поэтому, такая квалификация применима к данному виду правонарушения.

\section{2. Внесение изменений и дополнений в действующий Закон «О благотворительности»}

Как было сказано ранее, действующий Закон не содержит норм, регулирующих правила проведения сборов физическими лицами. По этой причине остро стоит вопрос о внесении поправок. К таковым можно отнести введение термина «непрозрачный сбор - благотворительный сбор, организуемый без какой-либо сопроводительной документации (документы, подтверждающие необходимость сбора)».

Также, касаемо сборов, организуемых физическими лицами, необходимо внести ряд требований:

- наличие документации, подтверждающей необходимость проведения сбора

- наличие расчетно-сметной документации, отображающей сумму сбора

- полный отчет о поступивших и потраченных средствах, с приложением подтверждающей документации

- наличие расчетного счета в банках второго уровня на территории Республики Казахстан

Необходимо рассмотреть возможность внедрения административной ответственности за организацию сбора, несоответствующего требованиям, и уголовной ответственности за повторное нарушение требований.

Анализ практики уголовных дел, касающихся «непрозрачных» сборов, показал, что большая их часть проводилась в социальных сетях.

Так, имеется необходимость в ограничении распространения информации о непроверенных сборах в средствах массовой информации и социальных сетях, а также учреждение административной ответственности за такие действия. 
Возникает необходимость в установлении признаков мошеннического сбора. Анализируя практику определения таких сборов, были выявлены следующие особенности:

- сбор активно ведется исключительно посредством опубликования в социальной сети;

- организаторы сбора оказывают эмоциональное давление на потенциальных жертвователей;

- как правило, точная сумма сбора не оглашается, сбор ведется по принципу «кто сколько сможет»;

- сбор ведется на личные банковские карты, без опубликования расчетного банковского счета;

- в ходе проведения сбора не публикуется необходимая документация, либо публикуются фотографии плохого качества, зачастую не имеющие юридически важных деталей, таких как печати;

- лица, организующие сбор, не публикуют данных полученных средствах;

- просьбы благотворителей о публикации отчетности вызывают агрессию со стороны организаторов сбора;

- отчет об использовании полученных средств не предоставляется.

Приведенные выше признаки являются собирательными, однако достаточно полно описывают благотво- рительный сбор, который может оказаться мошенническим.

Определенная сложность возникает в возбуждении уголовного дела, поскольку не каждая жертва такой лжеблаготворительности обращается в органы внутренних дел. С этой целью, предлагается ввести возбуждение уголовного по факту обнаружения такого мошеннического сбора.

В общественном понимании благотворительность базируется на открытости, честности, доверии, а главное - результативности. Однако мошеннические сборы все сильнее подрывают веру населения в прозрачность благотворительности, тем самым уменьшая вероятность помощи тем, кому она необходима.

Таким образом, проведя анализ действующего законодательства Республики Казахстан в сфере регулирования благотворительности, были выявлены проблемы и предложены меры их устранения. Вышеприведенные меры могут помочь повысить эффективность норм, регулирующих проведение благотворительных сборов физическими лицами и предотвратить мошеннические «непрозрачные» сборы.

\section{ЛИТЕРАТУРА}

1. Республика Казахстан. Закон № 402-V от 16 ноября 2015 года 0 благотворительности // Официальная правовая система нормативных правовых актов Республики Казахстан «Адилет» // http://adilet.zan.kz/rus/docs/Z1500000402 (был доступен 27 апреля 2020 года)

2. Республика Казахстан. Гражданский Кодекс от 1995 года // Официальная правовая система нормативных правовых актов Республики Казахстан «Адилет» // http://adilet.zan.kz/rus/docs/K940001000 (был доступен 27 апреля 2020 года)

3. Республика Казахстан. Уголовный кодекс от 2014 года // Официальная правовая система нормативных правовых актов Республики Казахстан «Адилет» // http://adilet.zan.kz/rus/docs/K1400000226 (был доступен 27 апреля 2020 года)

() Марцинечко Дарья Вадимовна ( daria.martsinechko@yandex.ru ). Журнал «Современная наука: актуальные проблемы теории и практики» 